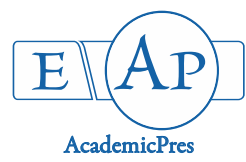

\title{
Variation in Agro-morphological Traits of Some Turkish Local Pop, Flint and Dent Maize (Zea mays L.)
}

\author{
Fatih ÖNER
}

University of Ordu, Faculty of Agricultural, Field Crops Department, 52200, Ordu, Turkey; fatihoner38@gmail.com

\begin{abstract}
Turkish maize accessions collected from north of Turkey were investigated for agro-morphologic variation in three maize kernel types (flint, pop and dent) including 79 accessions. Eight agronomic and morphologic traits (ear length, ear kernel row number, ear height, leaf number, 1000 kernel weight, tassel length, leaf width and leaf length) were analysed by ANOVA and principal component analysis. Varieties and accessions were found significantly different for variance components which were made up high variance due to accessions. Positive correlations were found between agronomic and morphologic traits. Multivariate discriminant function analysis with eight traits revealed that first two of multivariate correlation covered $86.6 \%$, and next $69 \%$ of total variation among accessions and the first multivariate discriminant function had high eigenvalue with $76.8 \%$ of total variance between varieties belonged to flint and pop maize accessions while the second multivariate variable belonged to flint and dent maize accessions. These multivariate variables correctly classify three maize varieties maintaining maize accessions for their various characteristics with agronomic and morphological traits.
\end{abstract}

Keywords: agronomic traits; maize genotypes; principal component analysis; Turkish maize accessions

\section{Introduction}

Contrary to the fact that maize consists of about 12.000 accessions and representing 256 varieties (Machado et al., 1998), only two percent of maize germplasm is used in maize breeding programs (Carvalho et al., 2004). Most of the present agro-morphological traits are still conserved traditionally by small farmers (Marshall, 1977); further available mixed cultivars in continental America displaying dent, flint and floury forms with different colors can be used in maize improvement (Paterniani, 2000; Abadie et al., 2000). The genetic variability among influential distinction provides a capable selection. The size of the genetic variability found in the population is of great importance for the success of any plant breeding program (Mohamed $e t$ al., 2012).

Following the introduction of maize to Anatolia by ottoman traders (1600 A.D.), its production usage was limited to small areas with traditional farming practices until the 1950s (Kün, 1994). There are three types of maize in Turkey that are flint maize, dent maize, and pop maize. Although flint maize is mainly planted in the Black Sea Region; dent maize, mostly planted at Aegean and Marmara Regions and even pop maize is planted in whole Turkey (Ilarslan et al., 2002). Harlan (1951) created maize collections from maize genotypes collected from Turkey and he observed that Turkish maize genotypes display heterogeneous variation.

Ilarslan et al. (2001) investigated the genetic composition of Turkish maize varieties using 19 isoenzyme markers for agronomic traits by sampling thirty-two maize accessions representing climatic, geographic and topographic regions of Turkey from the collections of USDA/ARS North Central Regional Plant Introduction Station (NCRPIS), Ames, Iowa. Ilarslan et al. (2002) suggested that there is a large amount of genetic variation exists in the maize varieties and accessions of Turkey and they may have lost their original genetic resources because of the changing in agricultural practices with high yielding genetic lines.

Morphological characterization is the first step in the identification and categorization of the genetic resources (Smith et al., 1990). Enough knowledge is needed on the importance of vital biological events and genetic diversity in plants for the effective protection, management and use of plant genetic resources (Iqbal et al., 2014). Agronomic and morphologic traits have large valuable information for breeding and conservation. Although there is a paper on the utilization of Turkish maize variety and accessions in Anatolia done by Ilarslan et al. (2002), it belongs to the seeds of maize collected by Harlan (1951) in 1948. The aim 
150

of this study is to utilize the genetic variation in terms of varieties and accessions of maize at the north of Anatolia using agronomic and morphologic traits by ANOVA and the principal component analysis of accessions and varieties comparing the study done by Ilarslan et al. (2002).

\section{Materials and Methods}

The accessions of seventy-nine germplasm were collected from different location and altitude of North of Turkey (Table 1).

These accessions were evaluated in the field during summer 2015 at the Agricultural Faculty of Ordu University, The City of Ordu, Turkey (altitude: $24 \mathrm{~m}$ ). The accessions were planted on May 15 in single-row-plots (30 plants per row) in a randomized block design. The measurements were done randomly on selected 6 individual plants in each row exceptional the edge rows. Row space was $0.70 \mathrm{~m}$ and within-row plant spacing was $0.20 \mathrm{~m}$. Various classification was done using eight traits, which are the most heritable and discriminatory agronomic and morphologic traits reported by several researchers (Sánchez et al., 1993; Revilla and Tracy, 1995; González Ugalde, 1997; Iqbal et al., 2015). These variables were utilized also by Ilarslan $e t$ al. (2002) in 32 Turkish accessions measuring directly. The traits were utilized in centimetre by counts and as rations from measurements (Table 1). Agro-morphological properties were assessed according to the properties set forth in IBPGR (IBPGR, 1991). Eight quantitative traits, namely, number of rows per ear (NRE, number of kernel rows around the cob at $5 \mathrm{~cm}$ from the shank of uppermost ear), ear height (EH, lenght of stem in $\mathrm{cm}$ from soil level), leaf number per plant (LN, calculated as number or leafs number of plants), 1000 kernel weight (TKW, mass of 1000 kernels in g adjusted to $18 \%$ moisture content), tassel lenght (TL, lenght is $\mathrm{cm}$ of tassel from flag leaf to tassel type), leaf width and leaf lenght (LW and LL, width and lenght in $\mathrm{cm}$, respectively, of leaf which under the ear per plant). The data were standardized calculating means and standard deviation for each trait within 79 accessions (Asare et al., 2016; Mitrović et al., 2016; Bouchet et al., 2017; Gazal et al., 2017).

ANOVA was used to analyze the significant differences among the accessions. Trait means were calculated for each maize accession. Data correlation matrix was constructed from the mean values and it was used in the principal component analysis to classify the 79 Turkish maize accessions. All statistical analyses were conducted with Statistical Software Package SPSS, 22 (IBM Corp. Released, 2013).

Table 1. Accession number, location of accessions, kernel type, and altitude of maize accessions

\begin{tabular}{|c|c|c|c|c|c|c|c|}
\hline Acces. No & Location & Kernel Type & Altitude & Acces. No & Location & Kernel Type & Altitude \\
\hline 1 & Samsun & Flint & 32 & 41 & Samsun & Flint & 54 \\
\hline 2 & Samsun & Flint & 45 & 42 & Samsun & Flint & 47 \\
\hline 3 & Samsun & Flint & 30 & 43 & Ordu & Flint & 243 \\
\hline 4 & Samsun & Flint & 48 & 44 & Samsun & Flint & 39 \\
\hline 5 & Samsun & Flint & 23 & 45 & Samsun & Flint & 46 \\
\hline 6 & Samsun & Flint & 55 & 46 & Samsun & Flint & 47 \\
\hline 7 & Tokat & Flint & 520 & 47 & Samsun & Flint & 51 \\
\hline 8 & Tokat & Flint & 618 & 48 & Samsun & Flint & 52 \\
\hline 9 & Tokat & Flint & 581 & 49 & Samsun & Flint & 55 \\
\hline 10 & Trabzon & Flint & 420 & 50 & Ordu & Flint & 234 \\
\hline 11 & Trabzon & Flint & 250 & 51 & Samsun & Flint & 55 \\
\hline 12 & Rize & Flint & 280 & 52 & Ordu & Dent & 229 \\
\hline 13 & Samsun & Flint & 35 & 53 & Ordu & Dent & 244 \\
\hline 14 & Rize & Flint & 678 & 54 & Samsun & Dent & 50 \\
\hline 15 & Samsun & Flint & 39 & 55 & Zonguldak & Flint & 500 \\
\hline 16 & Çorum & Flint & 467 & 56 & Zonguldak & Flint & 521 \\
\hline 17 & Ordu & Flint & 125 & 57 & Artvin & Flint & 1500 \\
\hline 18 & Karabük & Flint & 345 & 58 & Samsun & Flint & 55 \\
\hline 19 & Samsun & Flint & 605 & 59 & Giresun & Flint & 1000 \\
\hline 20 & Giresun & Flint & 818 & 60 & Trabzon & Flint & 155 \\
\hline 21 & Samsun & Flint & 35 & 61 & Karabük & Popcorn & 800 \\
\hline 22 & Samsun & Flint & 35 & 62 & Karabük & Popcorn & 800 \\
\hline 23 & Samsun & Flint & 35 & 63 & Samsun & Popcorn & 67 \\
\hline 24 & Artvin & Flint & 1210 & 64 & Samsun & Popcorn & 56 \\
\hline 25 & Ordu & Flint & 365 & 65 & Samsun & Popcorn & 34 \\
\hline 26 & Samsun & Flint & 68 & 66 & Samsun & Popcorn & 34 \\
\hline 27 & Karabük & Flint & 350 & 67 & Tokat & Popcorn & 903 \\
\hline 28 & Samsun & Flint & 35 & 68 & Trabzon & Popcorn & 874 \\
\hline 29 & Samsun & Flint & 44 & 69 & Çorum & Popcorn & 250 \\
\hline 30 & Trabzon & Flint & 235 & 70 & Trabzon & Popcorn & 200 \\
\hline 31 & Ordu & Flint & 130 & 71 & Çanakkale & Popcorn & 600 \\
\hline 32 & Samsun & Flint & 46 & 72 & Çanakkale & Popcorn & 600 \\
\hline 33 & Samsun & Flint & 43 & 73 & Çanakkale & Popcorn & 600 \\
\hline 34 & Samsun & Flint & 120 & 74 & Çanakkale & Popcorn & 345 \\
\hline 35 & Samsun & Flint & 112 & 75 & Çanakkale & Popcorn & 600 \\
\hline 36 & Trabzon & Flint & 150 & 76 & Çanakkale & Popcorn & 600 \\
\hline 37 & Trabzon & Flint & 165 & 77 & Bursa & Popcorn & 450 \\
\hline 38 & Samsun & Flint & 29 & 78 & Çanakkale & Popcorn & 678 \\
\hline 39 & Trabzon & Flint & 163 & 79 & Bingöl & Popcorn & 800 \\
\hline 40 & Samsun & Flint & 45 & & & & \\
\hline
\end{tabular}




\section{Results and Discussion}

The ANOVA analysis showed that there were significant differences between the agronomic and morphological traits among maize varieties and accessions (Table 2). As the mean and standard deviation indicated that the particularly studied traits had higher values in dent varieties than other two varieties (Table $2 \mathrm{a}$ ). The accessions within varieties also showed a significant variation for all traits. The similar results were obtained in a Turkish accession study by Ilarslan et al. (2002) the studied traits have been reported in the literature that they are highly heritable traits (Sanchez and Goodman, 1992; Sánchez et al., 1993; Revilla and Tracy, 1995; Mohammadi and Prasanna, 2003; Hugues et al., 2015). The high variance due to the within varieties indicates that accessions can have already utilized as" landraces" as a result of farmer's selection for many years (Ilarslan et al., 2002). Ilarslan et al. (2002) reported that most of the dent accessions came from the coastal regions where the growing season is longer and had the mild climate. Other two varieties (flint and pop maize) come from either coastal or inland region with a large of variation for growing season but mostly short. Farmers prefer flint and pop maize varieties because of the intense usage of them for human food in the coastal region and time-earning from the growing season for other alternative plants for winter. These three varieties can be classified due to their seed morphology such as kernel type.

The correlation between agronomic and morphologic traits was found as significant. For instance, ear height trait and other traits; leaf number, 1000-kernel weight, tassel length, leaf width, respectively, were correlated and positively significantly as $0.496,0.239,0.534,0.312$ and 0.553 . It has been observed a strong correlation between the 1000-kernel weight and leaf dimension traits (Table 3) except for tassel length trait. Negative correlations were found among the ear kernel row number and 1000-kernel weight, tassel length, leaf width, leaf length traits. This type of correlation between traits may result from the collection of many practiced in the study region. Turkish farmers usually collect seeds from former plants having better growth forms, morphological and agronomical, but there is no any selection procedure. The used seeds by farmers in the following year are limited to randomly bulked seed collections of the previous year. Maize is a cross pollinated species and although selection there is no isolation for maize plantations and flint and pop maize plants are grown in the same plantations in most of the farms. The seeds used in this study were collected from high and low altitude farms. Hybrid plants are preferred by low altitude farm owners allowing gene flow between growth plantations until $200 \mathrm{~m}$ (Luna et al., 2001). The negative correlation could be explained by the resource allocation.

The Fisher's linear discriminant functions and classification function coefficients showed that the most important traits in the classification are number of per ear (number), 1000-kernel weight $(\mathrm{g})$, tassel length $(\mathrm{cm})$, leaf width $(\mathrm{cm})$ and leaf length $(\mathrm{cm})$, respectively (Table 4$)$. Their classification function coefficients are given due to genotypes in Table 3. The preferable trait was found to be ear kernel row number for further studies.

Eight agronomic and morphologic traits were treated principal component analysis. The results showed that first two multivariate correlations covered $86.6 \%$ and second, $69 \%$ of the total variation among accessions. The first principal component function had high eigenvalue $(76.8 \%$ of the total variance between varieties) belonged to flint and pop maize accessions while the second multivariate variable belonged to flint and dent maize accessions (Table 4). These results showed that north Turkish maize accessions classified for their racial characteristics, which were grouped as flint, pop and dent maize accessions from the angle of seed collection and agronomic and morphologic traits by principal component analysis. Accessions 17 and 71 were considered as flint maize and accession 5 was considered pop maize before the analysis as misclassified (Fig. 1). The results of this present study are quite like the results obtained for the classification of maize varieties by Ilarslan $e t$ al. (2002). However, there was no relationship between pop and flint maize varieties the studied by enzyme polymorphism (Ilarslan et al., 2001) but the same study suggested that there could be a gene flow between flint and pop maize varieties.

The cross sections of the centroid of multivariate discriminant function in Fig. 1 showed that the centre of accessions is Ordu location.

Table 2. Mean squares of analysis for some agronomic-morphological traits among 79 local maize genotypes

\begin{tabular}{|c|c|c|c|c|c|c|c|c|}
\hline S.O.V. & $\mathrm{df}$ & EKN & $\mathrm{EH}$ & $\mathrm{LN}$ & TKW & TL & LW & $\mathrm{LL}$ \\
\hline Kernel Types & 2 & $66.92^{* *}$ & $3969.56^{* *}$ & 6.53 & $125972.5^{* *}$ & $185.61^{*}$ & $2.28^{*}$ & $458.85^{*}$ \\
\hline Genotypes & 76 & 7.54 & 1167.82 & 2.39 & 4873.7 & 48.62 & 0.72 & 104.70 \\
\hline Total & 78 & & & & & & & \\
\hline $\mathrm{CV}$ & & 25.79 & 39.34 & 12.90 & 33.04 & 18.81 & 12.80 & 15.23 \\
\hline
\end{tabular}

number, EH; Ear height (mm), LN; Leaf number (number), TKW; 1000-kernel weight (g), TL; Tassel length (mm), LW; Leaf width (cm), LL; Leaf length (cm).

Table 2a. Descriptive statistics for maize varieties (flint, pop and dent corn) like mean and standard deviation and Duncan group

\begin{tabular}{ccccccccc}
\hline Kernel Types & $\mathrm{N}$ & $\mathrm{EKN} \pm$ Std & $\mathrm{EH} \pm$ Std & $\mathrm{LN}$ & $\mathrm{TKW}$ & TL & LW \\
\hline Flint & 59 & $11.11 \pm 2.8 \mathrm{~b}$ & $88.71 \pm 35.6 \mathrm{~b}$ & $12.15 \pm 1.55$ & $298.23 \pm 72.6 \mathrm{a}$ & $38.45 \pm 7.5 \mathrm{~b}$ & $6.82 \pm 0.83 \mathrm{~b}$ & $69.89 \pm 10.05 \mathrm{~b}$ \\
Popcorn & 16 & $14.37 \pm 2.5 \mathrm{a}$ & $81.87 \pm 29.31 \mathrm{~b}$ & $12.12 \pm 1.54$ & $158.37 \pm 61.4 \mathrm{~b}$ & $36.00 \pm 4.8 \mathrm{~b}$ & $6.50 \pm 0.93 \mathrm{~b}$ & $67.14 \pm 11.53 \mathrm{~b}$ \\
Dent & 4 & $11.50 \pm 1.9 \mathrm{~b}$ & $131.25 \pm 27.8 \mathrm{a}$ & $14.00 \pm 1.41$ & $307.25 \pm 50.8 \mathrm{a}$ & $46.75 \pm 4.7 \mathrm{a}$ & $7.68 \pm 0.71 \mathrm{a}$ & $84.02 \pm 5.72 \mathrm{a}$ \\
Total & 79 & $11.79 \pm 3.01$ & $89.48 \pm 35.20$ & $12.24 \pm 1.57$ & $270.36 \pm 89.3$ & $38.37 \pm 7.22$ & $6.81 \pm 0.87$ & $70.05 \pm 10.66$ \\
\hline
\end{tabular}

Std: Standard Deviation 
Table 3. Correlation coefficients between agronomic and morphologic traits

\begin{tabular}{|c|c|c|c|c|c|c|c|}
\hline Traits & $\overline{E L}$ & NRE & $\overline{\mathrm{EH}}$ & LN & TKW & $\mathrm{TL}$ & $\begin{array}{l}\mathrm{LD} \\
\end{array}$ \\
\hline NRE & 0.187 & & & & & & \\
\hline $\mathrm{EH}$ & $0.342^{* *}$ & -0.102 & & & & & \\
\hline LN & $0.272^{* *}$ & 0.086 & $0.476^{* *}$ & & & & \\
\hline TKW & $0.291^{* *}$ & $-0.645^{* *}$ & 0.204 & 0.038 & & & \\
\hline $\mathrm{TL}$ & $0.298^{* *}$ & -0.099 & $0.524^{* *}$ & 0.165 & 0.178 & & \\
\hline LW & 0.186 & $-0.246^{*}$ & $0.402^{* *}$ & $0.348^{* *}$ & 0.220 & $0.309^{* *}$ & \\
\hline LL & $0.250^{*}$ & $-0.263^{*}$ & $0.560^{* *}$ & $0.386^{* *}$ & $0.288^{*}$ & $0.415^{* *}$ & $0.800^{* *}$ \\
\hline
\end{tabular}

${ }^{*}:$ significant $\mathrm{p}<0.05{ }^{* *}:$ significant $\mathrm{p}<0.01 . \mathrm{EL}=$ Ear length $(\mathrm{cm}), \mathrm{NRE}=$ number of rows per ear; $\mathrm{EH}=$ Ear height $(\mathrm{cm}), \mathrm{LN}=\mathrm{Leaf}$ number per plant (number), TKW $=1000$-kernel weight $(\mathrm{g}), \mathrm{TL}=$ Tassel length $(\mathrm{cm}), \mathrm{LW}=$ Leaf width $(\mathrm{cm}), \mathrm{LL}=$ Leaf length $(\mathrm{cm})$

Table 4. Fisher's linear discriminant functions and classification function coefficients

\begin{tabular}{cccc}
\hline \multirow{2}{*}{ Traits } & \multicolumn{3}{c}{ Kernel Types } \\
\cline { 2 - 4 } & Flint $(1)$ & Popcorn $(2)$ & Dent (3) \\
\hline NRE & 0.138 & 0.148 & 0.170 \\
TKW & 0.078 & 0.061 & 0.090 \\
TL & 0.034 & 0.077 & 0.077 \\
LW & 0.113 & 0.106 & 0.067 \\
LL & -0.027 & -0.042 & 0.016 \\
(Constant) & -91.269 & -101.831 & -140.259 \\
\hline
\end{tabular}

NRE; Ear kernel row number, TKW; 1000-kernel weight (g), TL; Tassel length (cm), LD; Leaf width (cm), LL; Leaf length (cm).

Table 5. Principal components analysis of 79 Turkish local genotypes evaluated in Ordu in 2015 using 8 agro-morphological traits

\begin{tabular}{ccc}
\hline Trait & PC 1 & PC 2 \\
\hline Ear length $(\mathrm{cm})$ & 0.738 & 0.351 \\
Ear kernel row number (number) & 0.388 & -0.019 \\
Ear height $(\mathrm{cm})$ & -0.130 & 0.698 \\
Leaf number (number) & -0.279 & 0.625 \\
1000-kernel weight $(\mathrm{g})$ & 0.137 & 0.464 \\
Tassel length $(\mathrm{cm})$ & 0.169 & 0.357 \\
Leaf width $(\mathrm{cm})$ & -0.229 & 0.310 \\
Leaf length $(\mathrm{cm})$ & 0.091 & 0.133 \\
Eigenvalues & 3.009 & 0.910 \\
Multivariate Correlation & 0.866 & 0.690 \\
Variance $(\%)$ & 76.8 & 23.2 \\
\hline
\end{tabular}

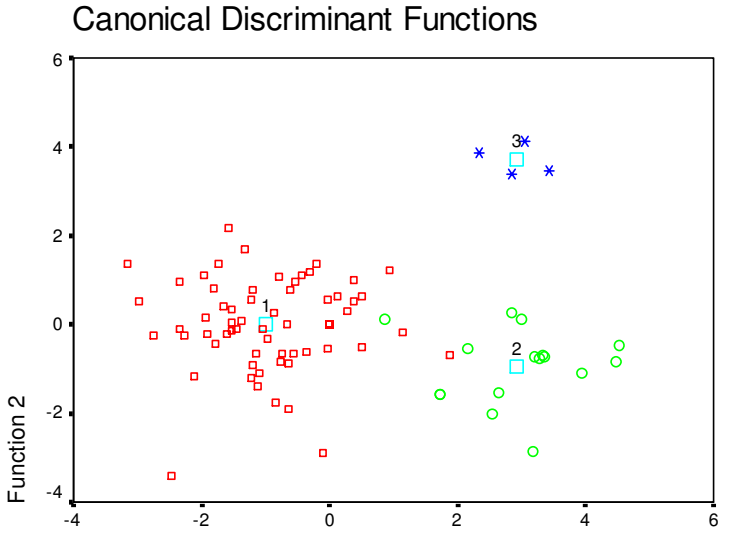

Function 1

Fig. 1. The grouping of Turkish maize accessions based on multivariate discriminant function analysis for agromorphological traits. Maize genotypes were displayed as Flint(1), Popcorn(2), and Dent (3)

\section{Conclusions}

The study indicates that maize accession collected from north of Turkey in 2010-2014 maintain considerable genetic variation in agronomic and morphologic traits at the level of either varieties or accessions. Further, Turkish seed collections are also available in NCRPIS. Ames. The USA collected local maize seeds in 1948-1952. If the results of this study compared with accessions (32 accessions) collected between 1948-1952 and 2015 years for the genetic composition of maize genetic resources of Turkey (Ilarslan et al., 2002), it seems that there is a higher variation between research years (68\% for 1948-1952 and $86.6 \%$ for 2015 ). The reason for this may come from the study area which is the north part of Turkey and most of the genotypes belong to flint type accessions. Breeder wants the variation to be high in order to be able to work from the genetic pool in breeding programs. If the breeder develops a silage corn, the number of leaves per plant and the size and width of the leaf are important criteria. For this reason, it makes the selection according to the parameters desired from the pool. In addition, because the areas where our work is done are very 
small, and in these areas, the farmers are protected by this material because of the aging of the planting areas and the loss of the young population. In addition to this suggestion, an introduction of high yielding genetic lines may increase the genetic variation. This study displays an informative knowledge of populations between years and preferable trait for selection to understand the background of accessions in following generations having a high adaptive capacity for the region and selection effect of farmers for the conservation of maize genetic resources.

\section{References}

Abadie T, Cordeiro C, Andrade RD, Parentoni S, Magalhaes J (2000). The nuclear collection of corn germplasm for Brazil. Plant Genetic Resources Newsletter 117:55-56.

Asare S, Tetteh AY, Twumasi P, Adade KB, Akromah RA (2016). Genetic diversity in lowland, midaltitude and highland African maize landraces by morphological trait evaluation. African Journal of Plant Science 10(11):246-257.

Bouchet S, Bertin P, Presterl T, Jamin P, Coubriche D, ... Charcosset A (2017). Association mapping for phenology and plant architecture in maize shows higher power for developmental traits compared with growth influenced traits. Heredity 118(3):249.

Carvalho VP, Ruas CF, Ferreira JM, Moreira M, Ruas PM (2004). Genetic diversity among maize (Zea mays L.) landraces assessed by RAPD markers. Genetics and Molecular Biology 27(2):228-236.

Gazal A, Nehvi F, Lone AA, Dar ZA (2017). Assessment of genetic variability of a set of maize inbred lines for drought tolerance under temperate conditions. International Journal of Current Microbiology and Applied Sciences 6(12):2380-2389.

González Ugalde WG (1997). Genetic characterization of Northern flints and flours maize (Zea mays L. spp. mays) with isozyme, SSR, and morphological markers. $\mathrm{PhD}$ Thesis, Iowa State University Capstones, Theses andDissertations. 11985. https://ib.driastate.edu/rtd/11985.

Harlan JR (1951). Anatomy of gene centres. The American Naturalist 85(821):97-103.

Hugues A, Akanvou L, Bi AIZ, Kouakou CK (2015). Phenotypic diversity of farmer's traditional maize (Zea mays $\mathrm{L}$ ) varieties in Cote d'Ivoire. Maydica 60(2015):M13.

IBPGR C (1991). Descriptors for maize. International Board for Plant Genetic Resources, Rome and International Maize and Wheat Improvement Center, Mexico City, Rome.

Ilarslan R, Kaya Z, Tolun A, Bretting P (2001). Genetic variability among Turkish pop, flint and dent corn (Zea mays L. spp. mays) races: Enzyme polymorphism. Euphytica 122(1):171-179.

Ilarslan R, Kaya Z, Kandemir I, Bretting P (2002). Genetic variability among Turkish pop, flint and dent corn (Zea mays L spp. mays) races: Morphological and agronomic traits. Euphytica 128(2):173-182.
Iqbal J, Shinwari ZK, Rabbani MA (2015). Maize (Zea mays L.) germplasm agro-morphological characterization based on descriptive, cluster and principal component analysis. Pakistan Journal of Botany 47:255-264.

Iqbal J, Shinwari ZK, Rabbani MA, Khan S (2014). Genetic variability assessment of maize (Zea mays L.) germplasm based on total seed storage proteins banding pattern using SDS-PAGE. European Academic Research 2(2):2144-2160.

Kün E (1994). Tahıllar II (Sıcak İklim Tahılları) Ankara Üniversitesi. Ziraat Fakultesi Yayınları No: 1360, Ders Kitabi No: 394, Ankara. [Cereals II (Warm Climate Cereals) Ankara University, Faculty of Agriculture, Publications No: 1360, TextbookNo: 394, Ankara].

Luna V, Figueroa M, Baltazar M, Gomez L, Townsend R, Schoper J (2001). Maize pollen longevity and distance isolation requirements for effective pollen control. CropScience 41(5):1551-1557.

Machado A, Pereira M, Pereira M, Machado CDT, Médice L (1998). Evaluation of local and improved maize varieties in different regions of Brazil. Crioulo maize: conservation and use of biodiversity. In: Soares AC, Machado AT, Silva BM, von der Weid JM (Eds.). Network Technologies Alternative Technologies, Rio de Janeiro pp 93-106.

Marshall D (1977). The advantages and hazards of genetic homogeneity. Annals of the New York Academy ofSciences 287(1):1-20.

Mitrović B, Stojaković M, Zorić M, Stanisavljević D, Bekavac G, ... Mladenov V (2016). Genetic gains in grain yield, morphological traits and yield stability of middle-late maize hybrids released in Serbia between 1978 and 2011. Euphytica211(3):321-330.

Mohamed S, Ali E, Mohamed T (2012). Study of heritability and genetic variability among different plant and fruit characters of tomato (Solanum lycopersicum L.). International Journal of Scientific \& Technology Research 1(2):55-58.

Mohammadi S, Prasanna B (2003). Analysis of genetic diversity in crop plants-salient statistical tools and considerations. Crop Science 43(4):1235-1248.

PaternianiE (2000). Origin and evolution of the species. Section 1.Evolution of corn in: Corn in Venezuela. Polar Foundation, pp 15-25.

Revilla P, Tracy W (1995). Morphological characterization and classification of open-pollinated sweet corn cultivars. Journal of the American Society for Horticultural Science 120(1):112-118.

Sanchez GJJ, Goodman MM (1992). Relationships among the Mexican races of maize. Economic Botany 46(1):72-85.

Sanchez J, Goodman M, Rawlings J (1993). Appropriate characters for racial classification in maize. Economic Botany $47(1): 4459$.

Smith O, Smith J, Bowen S, Tenborg R, Wall S (1990). Similarities among a group of elite maize inbreeds as measured by pedigree, F1 grain yield, grain yield, heterosis, and RFLPs. Theoretical and Applied Genetics 80(6):833-840 